\title{
UJI AKTIVITAS PENANGKAP RADIKAL BEBAS DAN PENETAPAN KADAR FENOLIK TOTAL EKSTRAK ETANOL TIGA RIMPANG GENUS CURCUMA DAN RIMPANG TEMU KUNCI (Boesenbergia pandurata)
}

\section{RADICAL SCAVENGING ACTIVITY ASSAY AND DETERMINATION OF TOTAL PHENOLIC CONTENT OF ETHANOL EXTRACT THREE CURCUMA GENUS RHIZOMES AND FIGERROOT RHIZOME (Boesenbergia pandurata)}

\author{
Rosita Melannisa, Muhammad Da'i ${ }^{\star}$, Ratih Tiastika Rahmi \\ Fakultas Farmasi, Universitas Muhammadiyah Surakarta \\ abulathfi@gmail.com
}

\begin{abstract}
ABSTRAK
Radikal bebas bersifat sangat reaktif sehingga sangat mudah menyerang sel- sel sehat di dalam tubuh yang berujung pada timbulnya suatu penyakit. Tubuh memerlukan antioksidan dari luar untuk melindungi tubuh dari serangan radikal bebas. Beberapa jenis curcuma dan rimpang temu kunci mengandung senyawa fenolik yang mempunyai aktivitas antioksidan. Penelitian ini dilakukan untuk mengetahui korelasi antara aktivitas penangkap radikal bebas dan kadar fenolik yang terdapat dalam rimpang kunyit (Curcuma domestica), rimpang temulawak (Curcuma xanthorriza), rimpang temu putih (Curcuma zedoaria) dan rimpang temu kunci (Boesenbergia pandurata). Penentuan potensi aktivitas penangkap radikal bebas menggunakan metode DPPH dengan pembanding vitamin E. Kadar fenolik total diukur sebagai GAE menggunakan pereaksi Folin-Ciocalteu. Besarnya korelasi dihitung menggunakan persamaan regresi linear dan dilihat nilai $R^{2}$. Aktivitas penangkap radikal bebas (IC $\left.{ }_{50}\right)$ ekstrak etanol rimpang kunyit $(29,64 \mu \mathrm{g} / \mathrm{mL})$ memiliki aktivitas paling tinggi, tetapi lebih rendah dari vitamin $E(12,55 \mu \mathrm{g} / \mathrm{mL})$. Kadar fenolik total (GAE) tertinggi adalah ekstrak etanol rimpang rimpang kunyit $(179,71 \mathrm{mg} / \mathrm{g})$. Terdapat korelasi positif antara aktivitas penangkap radikal bebas dan kadar fenolik total dalam empat ekstrak tersebut dengan koefisien korelasi $R^{2}=79,56 \%$.
\end{abstract}

Kata kunci: antioksidan, fenolik total, DPPH, korelasi.

\section{ABSTRACT}

The body needs external antioxidants to protect the body from free radical attack. Several types of curcuma and temu kunci contain phenolic compounds that have antioxidant activity. The aim of this research is to determine the correlation between the radical scavenging activity and the phenolic content of the ethanol extract of turmeric rhizome (Curcuma domestica), temulawak rhizome (Curcuma xanthorriza), zedoary rhizome (Curcuma zedoaria) and temu kunci rhizome (Boesenbergia pandurata). The DPPH was used to determine the radical scavenging activity with vitamin $E$ as a positive control. Determination of total phenolic content is used Folin-Ciocalteu reagent and measured as GAE. The correlation was calculated using a linear regression equation and $R^{2}$. The highest total phenolic content (GAE) ethanol extract of rhizome is the turmeric rhizome $(179.71 \mathrm{mg} / \mathrm{g})$. It is also has the highest radical scavenging activity $\left(I C_{50}=29.64 \mu \mathrm{g} / \mathrm{mL}\right)$, but its activity is lower than vitamin $E\left(I C_{50}=12.55 \mu \mathrm{g} / \mathrm{mL}\right)$. There is a positive correlation between radical scvenging activity and total phenolic content in the four of extract with correlation coefficient $R^{2}=$ $79.56 \%$.

Keywords: antioxidant, total phenolic, DPPH, correlation.

\section{PENDAHULUAN}

Radikal bebas dapat didefinisikan sebagai molekul atau senyawa yang mempunyai satu atau lebih elektron bebas yang tidak berpasangan (Hernani dan Raharjo, 2006). Radikal bebas dapat dihasilkan dari hasil metabolisme tubuh dan juga dari luar tubuh seperti asap rokok, polusi lingkungan, radiasi, obat-obatan, pestisida, serta sinar ultraviolet (Langseth, 1995).
Tubuh memerlukan substansi penting, yaitu antioksidan yang dapat membantu melindungi tubuh dari serangan radikal bebas dengan meredam dampak negatif senyawa radikal bebas tersebut. Antioksidan adalah substansi yang dapat menghambat atau menangkal proses oksidasi pada konsentrasi rendah (Vaya dan Aviram, 2001).

Beberapa antioksidan dapat dihasilkan dari produk alami seperti rempah, herba, 
sayuran, dan buah. Tanaman obat mempunyai daya aktivitas antioksidan lebih tinggi bila dibandingkan dengan buah dan sayuran (Hernani dan Raharjo, 2006).

Genus Curcuma dan Boesenbergia yang termasuk famili Zingiberaceae telah lama dimanfaatkan dalam pengobatan tradisional dan dapat dikembangkan sebagai antioksidan. Kurang lebih 20 jenis Curcuma, seperti $C$. xanthorriza, C. domestica, C. zedoaria dan lainnya tumbuh di Indonesia (Afifah dkk., 2003). Beberapa jenis kurkuma telah diteliti mengandung senyawa kimia yang disebut sebagai kurkuminoid (kurkumin 75\%, demetoksikurkumin $15-20 \%$ dan bisdemetoksikurkumin kurang lebih $3 \%$ ). Kurkuminoid merupakan kelompok senyawa fenolik yang mempunyai sifat antioksidan dan antiradang (Anonim, 2007). Selain kurkuminoid ditemukan pula kandungan senyawa fenolik lain, seperti flavonol kuersetin, kaempferol, mirisetin dan luteolin dalam genus Curcuma (Hartati dkk., 2003; Andarwulan dkk., 2010).

Panduratin A dalam rimpang Boesenbergia pandurata merupakan derivat kalkon yang mempunyai efek biologis, seperti antiinflamasi, analgetik, antikanker dan antioksidan (Yun et al., 2006 cit. Geonadi, 2009). Aktivitas antiradikal suatu ekstrak dapat dipengaruhi oleh kadar fenolik totalnya (Utami dkk., 2005).

Penelitian ini dilakukan untuk mengetahui korelasi antara aktivitas penangkap radikal dan kadar fenolik yang terdapat dalam rimpang dengan genus Curcuma ( $C$. xanthorriza, $C$. domestica, C. zedoaria) dan rimpang temu kunci (B. pandurata).

\section{METODE PENELITIAN}

Bahan: ekstrak etanol rimpang C. xanthorriza, C. domestica, C. zedoaria, dan B. pandurata yang diperoleh dari Fakultas Farmasi Universitas Muhammadiyah Surakarta, DPPH (2,2- diphenyl-1-picrylhydrazyl), etanol p.a, etanol teknis, akuabidestilata, vitamin $\mathrm{E}$, asam galat, reagen Folin-Ciocalteau, $\mathrm{Na}_{2} \mathrm{CO}_{3}$, alumunium foil, lempeng KLT.

\section{Jalannya Penelitian \\ Penentuan kadar fenolik total}

Berdasarkan Chun et al. (2003) yang telah dimodifikasi, penentuan kadar total senyawa fenolik ekstrak dengan metode FolinCiocalteau. Dengan menggunakan asam galat sebagai sebagai baku. Nilai yang diperoleh merupakan ekuivalensi miligram asam galat tiap gram ekstrak (Gallic Acid Equivalent / GAE).

\section{Uji aktivitas antioksidan (metode DPPH)}

Sejumlah larutan stok sampel ekstrak etanol rimpang C. xanthorriza, C. domestica, $C$. zedoaria, $B$. pandurata serta vitamin E dengan lima seri konsentrasi, ditempatkan dalam labu takar $5,0 \mathrm{~mL}$. Sampel selanjutnya ditambah dengan $0,7 \mathrm{~mL}$ DPPH $0,4 \mathrm{mM}$ dan ditambah etanol hingga tanda. Campuran tersebut divorteks selama 30 detik dan diinkubasi selama 30 menit.

Absorbansi sampel diukur menggunakan spektrofotometer UV-Vis (Simadzu) terhadap blangko yang terdiri dari sejumlah larutan stok dalam etanol pada $\lambda$ maks $517,6 \mathrm{~nm}$. Selain itu, dibandingkan dengan kontrol yang terdiri dari 0,7 mL DPPH 0,4 mM dalam etanol. Dihitung \% aktivitas antiradikal. Dibuat kurva regresi linier antara konsentrasi melawan \% aktivitas antiradikal. Didapatkan rumus regresi linier dan ditentukan konsentrasi sampel pada aktivitas $50 \%$.

\section{HASIL DAN PEMBAHASAN}

Ekstrak yang digunakan sebagai sample adalah ekstrak yang diperoleh dari fakultas farmasi Universitas Muhammadiyah Surakarta, berupa ekstrak kental yang diperoleh dengan cara maserasi.

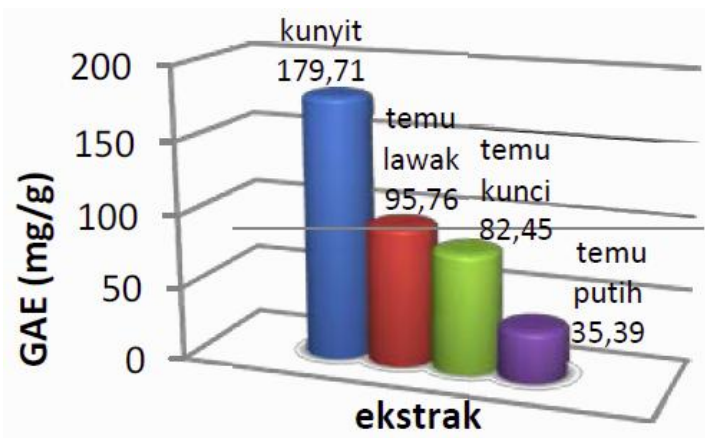

Gambar 1- Hasil Penetapan Kadar Fenolik Total

\section{Kadar fenolik total}

Penetapan kadar fenolik total dapat menggunakan pereaksi Folin-Ciocalteu. Mekanisme dari metode ini berdasarkan kekuatan mereduksi dari gugus hidroksi fenolik. Semua senyawa fenolik termasuk fenol sederhana dapat bereaksi dengan reagen Folin Ciocalteu (Huang et al., 2005). Adanya inti aromatis pada senyawa fenol (gugus hidroksi fenolik) dapat mereduksi fosfomolibdat fosfotungstat menjadi molybdenum yang berwarna biru (Sudjadi dan Rohman, 2004). Kadar fenolik total empat ekstrak etanol dari yang tertinggi adalah temulawak $(95,76 \mathrm{mg} / \mathrm{g})$, rimpang temu putih $(35,39 \mathrm{mg} / \mathrm{g})$ (Gambar 1). 


\section{Aktivitas penangkap radikal bebas}

Aktivitas antiradical ditentukan dari kemampuan senyawa yang terdapat dalam ekstrak untuk menurunkan intensitas warna ungu radikal DPPH pada panjang gelombang maksimum (Rohman dan Riyanto, 2006). Penurunan intensitas warna ungu DPPH ini disebabkan oleh berkurangnya kromofor atau ikatan rangkap terkonjuggasi pada senyawa $\mathrm{DPPH}$, yang disebabkan oleh adanya ekstrak sebagai penangkap radikal akan mendonorkan atom $\mathrm{H}$ pada DPPH menjadi DPPH-H tereduksi yang menjadi warna kuning (Huang et al., 2005).

Diperoleh aktivitas penangkap radikal bebas berturut-turut dari IC50 yang terkecil yaitu Vitamin $E(12,55 \pm 2,53 \mu \mathrm{g} / \mathrm{mL})$, ekstrak kunyit $(29,64 \pm 0,83 \mu \mathrm{g} / \mathrm{mL})$, ekstrak temulawak $(58,45 \pm 5,06 \mu \mathrm{g} / \mathrm{mL})$, ekstrak temu kunci $(140,21 \pm 8,35 \mu \mathrm{g} / \mathrm{mL})$, ekstrak temu putih $(170, \pm 783,03 \mu \mathrm{g} / \mathrm{mL}$ ) (Gambar 2). Dari empat ekstrak yang diuji, tidak ada ekstrak yang mempunyai potensi aktivitas antioksidan yang lebih kuat disbanding vitamin $\mathrm{E}$ karena dari keempat ekstrak yang diuji tidak ada yang memiliki $\mathrm{IC}_{50}$ lebih kecil dari vitamin $\mathrm{E}$.

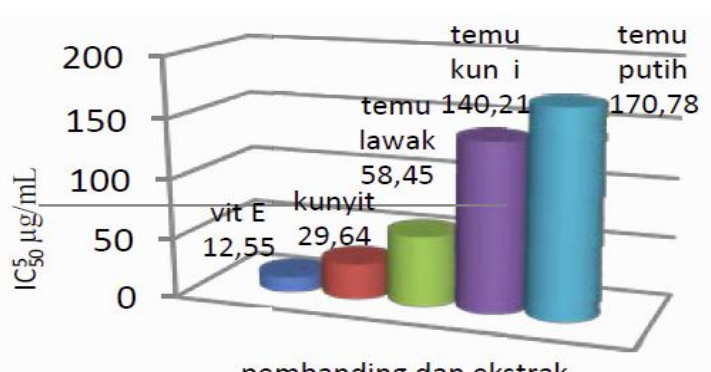

pembanding dan ekstrak

Gambar 2- Kunyit, Temulawak, Temu Kunci, dan Temu Putih dibandingkan dengan vitamin E.

\section{Korelasi antara aktivitas penangkap radikal bebas dan kadar fenolik total}

Dari hasil penelitian menunjukkan aktivitas penangkap radikal bebas $\left(\mathrm{IC}_{50}\right)$ dan kadar fenolik total (GAE) dalam ekstrak kunyit $(29,64 \mu \mathrm{g} / \mathrm{mL} ; 179,71 \mathrm{mg} / \mathrm{g})$, rimpang temulawak $(58,45 \mu \mathrm{g} / \mathrm{mL} ; 95,76 \mathrm{mg} / \mathrm{g})$, rimpang temu kunci $(140,21 \mu \mathrm{g} / \mathrm{mL} ; 89,45 \mathrm{mg} / \mathrm{g})$ dan rimpang temu putih $(170,78 \mu \mathrm{g} / \mathrm{mL}$; $35,39 \mathrm{mg} / \mathrm{g}$ ). Semakin tinggi kadar fenolik total yang terdapat di dalam ekstrak maka semakin besar pula potensi aktivitas antioksidannya. Korelasi kandungan fenolik dan aktivitas antioksidan yang terdapat dalam rimpang diketahui dari koefisien korelasi $\left(\mathrm{R}^{2}\right)$ dari persamaan regresi linear antara aktivitas antioksidan dan kadar fenolik total.

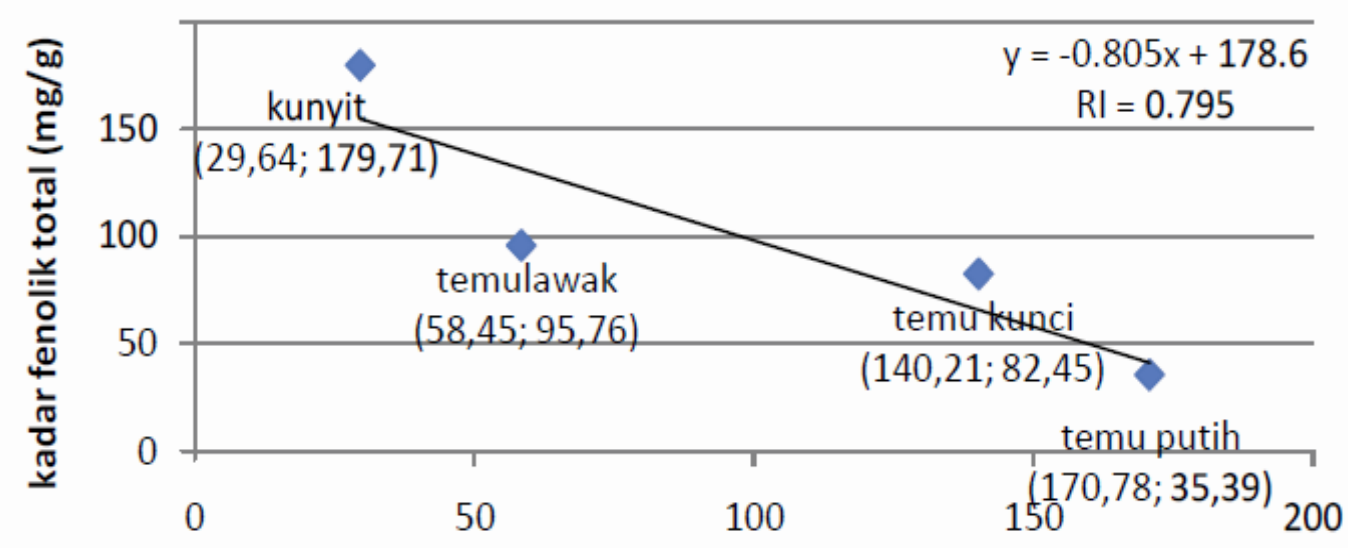

rerata $\mathrm{IC}_{50}(\mu \mathrm{g} / \mathrm{mL})$

Gambar 3- Grafik hubungan $\mathrm{IC}_{50}$ dengan kadar Fenolik total

Aktivitas antioksidan tiap ekstrak berkolerasi positif dengan kadar fenolik total dalam ekstrak $\left(R^{2}=0,7956\right)($ Gambar 3). Hal ini berarti $79,56 \%$ aktivitas antioksidan ekstrak etanol empat ekstrak disumbangkan oleh senyawa fenolik. Senyawa-senyawa fenolik yang telah terbukti memiliki aktivitas penangkap radikal dari empat ekstrak etanol yang diteliti adalah senyawa kurkuminoid (kurkumin, demetoksikurkumin dan bisdemetoksikurkumin), xanthorizol dan panduratin A (Song, 2001 cit. Achmad dkk. 2007; Yun et al., 2006 cit. Geonadi dkk., 2009; Irawati, 2008). Aktivitas antioksidan ekstrak yang diteliti 79,56\% disumbangkan oleh senyawa fenolik yang dikandungnya. Sedangkan selebihnya kemungkinan dari senyawa lain seperti vitamin $\mathrm{C}$ atau betakaroten (Vaya dan Aviram, 2001) dimana senyawa tersebut dapat menyumbangkan proton sehingga menstabilkan radikal bebas dan mempunyai aktivitas penangkap radikal bebas. Senyawa marker yang terdapat pada ekstrak yang diuji adalah kurkuminoid, tetapi tidak ditemukan pada ekstrak rimpang temu kunci ( $B$. pandurata). Kadar fenolik tertinggi terdapat 
pada ekstrak kunyit ( $C$. domestica) dapat diindikasikan pula dengan tingginya kadar fenolik maka tinggi pula kadar kurkuminoidnya sehingga aktivitas penangkap radikal bebas makin kuat.

Dari hasil penelitian ini menunjukkan bahwa ekstrak etanol rimpang kunyit, temulawak, temu kunci dan temu putih terbukti mengandung senyawa yang mempunyai aktivitas sebagai penangkap radikal bebas. Semakin tinggi kadar fenolik total maka aktivitas penangkap radikal bebas juga meningkat.

\section{KESIMPULAN}

Empat ekstrak etanol rimpang yang diuji memiliki aktivitas penangkap radikal $\left(\mathrm{IC}_{50}\right)$ yaitu kunyit $(29,64 \mu \mathrm{g} / \mathrm{mL})$, temulawak $\quad(58,45$ $\mu \mathrm{g} / \mathrm{mL})$, temu kunci $(140,21 \mu \mathrm{g} / \mathrm{mL})$, temu putih $(170,78 \mu \mathrm{g} / \mathrm{mL})$. Dari empat ekstrak yang diuji aktivitas antioksidannya tidak ada yang lebih kuat dibandingkan dengan vitamin E (12,55 $\mu \mathrm{g} / \mathrm{mL})$.

Kadar fenolik total (GAE) ekstrak etanol rimpang yang diteliti yaitu kunyit $(179,71 \mathrm{mg} / \mathrm{g})$, temulawak $(95,76 \mathrm{mg} / \mathrm{g})$, temu kunci $(89,45$ $\mathrm{mg} / \mathrm{g})$ dan temu putih $(35,39 \mathrm{mg} / \mathrm{g})$.

Terdapat korelasi positif antara aktivitas antioksidan dan kadar fenolik total dalam ekstrak. 79,56 \% aktivitas antioksidan ekstrak etanol empat ekstrak disumbangkan oleh senyawa fenolik.

\section{DAFTAR PUSTAKA}

Achmad, S. A., Hakim, E. H., Makmur, L., Syah, Y.M., Juliwaty, L. D., dan Mujahidin, D., 2007, Tumbuh-tumbuhan Obat Indonesia, Jilid 2, Penerbit ITB, Bandung.

Afifah, E., Tim Lentera, 2003, Khasiat dan Manfaat Temulawak Rimpang Penyembuh Aneka Penyakit, Agromedia Pustaka, Tangerang.

Andarwulan, N., Batari, R., Sandrasari, D.A., Bolling, B., dan Wijaya, H., 2010, Flavonoid content and antioxidant activity of vegetables from Indonesia, Food Chemistry, 121, 1231-1235.

Anonim, 2007, Temu Putih, Departemen Kesehatan RI, Jakarta.

Chun, O. K., Kim, D-O. And Lee, C. Y., 2003, Superoxide Radical Scavenging Activity of the Major Polyphenols in Fresh Plums, Journal of Agricultural and Food Chemistry, 51, 8067-8072.

Geonadi, F. A., Fitria, M., Ayu, D. P., dan Sulistyorini , E., 2009, Temu Kunci (Boesenbergia pandurata), (online), (http://ccrcfarmasiugm.wordpress.com/ensiklopedia-tanaman-antikanker/t/temu- kunci/), diakses pada 25 Agustus 2010.

Hartati, M.S., Mubarika, S., Bolhuis, R.L.H., Nooter, K., Oostrum, R.G., Boersma, A.M.H., dan Wahyuono, S., 2003, Sitotoksisitas rimpang temu mangga (Curcuma Mangga Val. \& V. Zijp.) dan kunir putih (Curcuma Zedoaria I.) terhadap beberapa sel kanker manusia (in vitro) dengan metoda SRB, Berkala IImu Kedokteran, 35, 4, 197-201.

Hernani dan Raharjo, M., 2006, Tanaman Berkhasiat Antioksidan, Penebar Swadaya, Jakarta.

Huang, D., Ou, B., and Prior, R.L., 2005, The Chemistry behind Antioxidant Capacity Assays, Journal of Agricultural and Food Chemistry, 53, 1841-1856.

Langseth, L., 1995, Oxidants, Antioxidans, and Disease Prevention, International Life Sciences Institutes (ILSI) Europe, Belgium.

Rohman, A. dan Riyanto, S., 2006, Aktivitas Antiradikal Bebas Ekstrak Kloroform Buah Mengkudu (Morinda citrifolia, L.) dan Fraksi-fraksinya, Artocarpus, 6, 1, 39.

Utami, W., Dai, M., dan Sofiana Y. R.,2005, Aktivitas Penangkap Radikal Dengan Metode DPPH Serta penetapan Kandungan Fenol dan Flavonoid Dalam Ekstrak Kloroform, Ekstrak Etil Asetat, Ekstrak Etanol Daun Dewandaru (Eugenia uniflora L.), Pharmacon, 6, 5-9.

Vaya, J., and Aviram, M., 2001, Nutritional Antioxidants: Mechanisms of Action, Analyses of Activities and Medical Applications, Curr. Med. Chem.-Imm, Endoc. \& Metab. Agents, 1, 1. 